\title{
N. L. Breton de Hauteroche, Théâtre complet
}

\section{Monica Pavesio}

\section{OpenEdition}

\section{Journals}

\section{Edizione digitale}

URL: http://journals.openedition.org/studifrancesi/442

DOI: 10.4000/studifrancesi.442

ISSN: 2421-5856

\section{Editore}

Rosenberg \& Sellier

\section{Edizione cartacea}

Data di pubblicazione: 1 aprile 2015

Paginazione: 144-145

ISSN: 0039-2944

\section{Notizia bibliografica digitale}

Monica Pavesio, « N. L. Breton de Hauteroche, Théâtre complet», Studi Francesi [Online], 175 (LIX | I) |

2015, online dal 01 avril 2015, consultato il 18 septembre 2020. URL : http://journals.openedition.org/ studifrancesi/442 ; DOI : https://doi.org/10.4000/studifrancesi.442

Questo documento è stato generato automaticamente il 18 settembre 2020 .

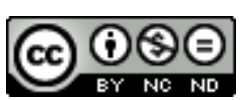

Studi Francesi è distribuita con Licenza Creative Commons Attribuzione - Non commerciale - Non opere derivate 4.0 Internazionale. 


\title{
N. L. Breton de Hauteroche, Théâtre complet
}

\author{
Monica Pavesio
}

\section{NOTIZIA}

N. L. BRETON DE HAUTEROCHE, Théâtre complet, Edition de A. BLANC, Paris, Classique Garnier, 2014, vol. I pp. 665, vol. II pp. 611.

1 L'opera teatrale di Noël Le Breton, signore di Hauteroche, drammaturgo e attore, contemporaneo e successore di Molière, è oggi sconosciuta. Eppure le dodici commedie del drammaturgo (una delle quali rimasta manoscritta e oggi perduta), alcune comiche, altre contenenti una satira piccante della società, ebbero un grande successo, nella Francia di fine Seicento.

2 L'edizione moderna di A. Blanc, prima edizione completa delle opere di Hauteroche (se si esclude un'edizione pirata pubblicata in Olanda nel 1683) è suddivisa in due volumi. Il primo volume contiene un'introduzione generale - nella quale l'autore ripercorre la lunga carriera d'attore di Hauteroche, la sua vita privata, le sue qualità come drammaturgo - e le sue prime sei commedie L'Amant qui ne flatte point, Le Souper mal apprêté, Crispin médecin, Le Deuil, Les Apparences trompeuses e Crispin musicien. Il secondo volume raccoglie altre cinque commedie del drammaturgo Les Nobles de province, L'Esprit follet, Le Cocher, Le Feint Polonais e Les Bourgeoises de qualité e una sua lettera sulla Sophonisbe di Corneille.

3 Tutte le opere sono precedute da una breve presentazione, da un apparato di note esplicative e dalle varianti. Un glossario, una breve bibliografia, un indice dei nomi e delle opere concludono il secondo volume. 